\title{
AKTIVITAS PENANGKAP RADIKAL BEBAS EKSTRAK ETANOL KULIT BUAH NAGA DENGAN METODE DPPH (1,1-DIFENIL-2-PIKRILHIDRAZIL)
}

\author{
Titiek Martati*, Gigin Devita S. \\ Fakultas Farmasi, Universitas Pancasila, Jagakarsa, Jakarta 12640 \\ *Email: titiekmartati@gmail.com
}

\begin{abstract}
ABSTRAK
Antioksidan merupakan senyawa yang dapat menghambat reaksi oksidasi dengan mengikat radikal bebas dan molekul yang sangat reaktif. Buah naga merupakan salah satu sumber antioksidan alami, merupakan satu jenis buah tropis dengan kandungan polifenol. Kulit buah naga merupakan limbah yang jarang dimanfaatkan, padahal kulit buah naga mengandung senyawa antioksidan kuat. Penelitian ini bertujuan untuk mengetahui aktivitas antioksidan sebagai penangkap radikal bebas dari ekstrak etanol $70 \%$ kulit buah naga merah (Hylocereus polyrhizus (F.A.C Weber) Britton \& Rose) dan naga putih (Hylocereus undatus (Haw.) Britton \& Rose) dengan metode DPPH (1,1-difenil-2-pikrilhidrazil). Ekstrak etanol $70 \%$ dibuat dengan metode maserasi, uji aktivitas antioksidan dilakukan dengan metode DPPH secara spektrofotometri visibel dengan vitamin $\mathrm{C}$ sebagai kontrol positif. Akivitas penangkap radikal bebas ekstrak etanol $70 \%$ dinyatakan dalam $\mathrm{IC}_{50}$. Hasil penelitian menunjukkan bahwa ekstrak etanol $70 \%$ kulit buah naga merah dan naga putih memiliki aktivitas sebagai penangkap radikal bebas. Nilai $\mathrm{IC}_{50}$ ekstrak kulit buah naga merah $(76,19 \pm 2,44) \mu \mathrm{g} / \mathrm{ml}$ dan kulit buah naga putih memiliki nilai $\operatorname{IC}_{50}(101,75 \pm 2,13)$ $\mu \mathrm{g} / \mathrm{ml}$, sedangkan vitamin $\mathrm{C}$ memiliki nilai $\mathrm{IC}_{50} 3,81 \mu \mathrm{g} / \mathrm{ml}$. Berdasarkan tabel anova data berbeda bermakna, menunjukkan adanya perbedaan aktivitas penangkap radikal bebas antara kulit buah naga merah dan naga putih.
\end{abstract}

Kata Kunci: Radikal bebas, Kulit buah naga,Vit.C, DPPH (1,1-difenil-2-pikrilhidrazil)

\section{PENDAHULUAN}

Buah naga merupakan jenis kaktus dengan famili Cactaceae, merupakan salah satu jenis buah tropis dengan kandungan polifenol dan merupakan salah satu sumber antioksidan yang alami (1). Kulit dari buah naga merupakan limbah yang jarang dimanfaatkan. Padahal kulit buah naga masih mengandung senyawa penangkap radikal bebas yang cukup tinggi. Berdasarkan penelitian yang dilakukan sebelumnya (2), ekstrak n-heksan kulit buah naga merah memiliki aktivitas antioksidan dengan nilai IC $_{50}$ sebesar 206,5 $\mu \mathrm{g} / \mathrm{mL}$, aktivitas antioksidan fraksi n-heksan ini tergolong kurang aktif. Berdasarkan hasil tersebut, maka dilakukan penelitian untuk mengetahui aktivitas penangkap radikal bebas dari ektrak etanol $70 \%$ dan apakah terdapat perbedaan aktivitas penangkap radikal bebas antara kulit buah naga merah dan kulit buah naga putih. Aktivitas penangkap radikal bebas dilakukan dengan metode DPPH (1,1-difenil-2-pikrilhidrazil) menggunakan spektrofotometri UV-Vis dengan vitamin C sebagai kontrol positif (3). Parameter adanya aktivitas penangkap radikal bebas yang dimiliki ekstrak etanol ditunjukkan oleh \% inhibisi dan $\mathrm{IC}_{50}$. 


\section{METODE PENELITIAN}

\section{Bahan.}

Serbuk simplisia kulit buah naga merah dan kulit buah naga putih yang diperoleh dari Balai Penelitian Tanaman Obat dan Aromatika ( BALITTRO) Bogor. Daerah pengambilan buah naga terdapat diperkebunan Subang Jawa Barat

\section{Peralatan.}

Timbangan analitik ( AND GR 200 ), timbangan microbalance (mettler MT5), spektrofotometer UV-Vis ( Shimadzu Uv-Vis 1700), vakum rotavapor ( IKA® RV 10 control ), oven ( Memmert ).

\section{Prosedur.}

\section{Determinasi Tanaman.}

Sebelum dilakukan penelitian, dilakukan determinasi terhadap buah naga merah dan naga putih. Determinasi dilakukan di " Herbarium Bogoriense", Bidang Botani Pusat penelitian Biologi - LIPI ( lembaga ilmu pengetahuan Indonesia ), Cibinong, Bogor.

\section{Pembuatan Ekstrak.}

Sejumlah simplisia kulit buah naga kering ditimbang kurang lebih 500g, dimasukkan kedalam bejana maserasi dan ditambahkan pelarut etanol 70\%, sebanyak 200 $\mathrm{mL}$ sampai semua sampel terendam oleh pelarut. Maserasi dilakukan selama 5 hari, setiap 24 jam pelarut diganti dan dilakukan pengadukan tiga kali sehari selama 2,5 - 3 jam. Hasil maserasi disaring untuk memisahkan filtrat dan residunya, filtrat yang diperoleh dikumpulkan dan disaring. Kemudian filtrat tersebut dipekatkan menggunakan rotavapor pada suhu $\pm 40^{\circ} \mathrm{C}$ hingga pelarut menguap dan menjadi ekstrak kental (4), ditimbang dan dihitung $\%$ rendemen, dengan rumus sebagai berikut :

$$
\text { Rendemen }(\%)=\quad \begin{aligned}
& \text { Bobot ekstrak diperoleh } \\
& \text { Bobot bahan yang ditimbang }
\end{aligned} \times 100 \%
$$

\section{Penapisan fitokimia.}

Dilakukan uji kualitatif adanya senyawa antioksidan. Uji kualitatif adanya alkaloid menggunakan pereaksi Dragendorff, uji flavonoid menggunakan serbuk magnesium dan amil alkohol, uji tanin menggunakan larutan $\mathrm{FeCl} 31 \%$, uji steroid dan triterpenoid menggunakan pereaksi Lieberman-Burchard (4).

\section{Uji Parameter Mutu Ekstrak. (4)}

\section{Penetapan kadar air.}

Sejumlah ekstrak ditimbang sejumlah kurang lebih 40 mg kemiudian dimasukan kedalam alat uji Karl Ficher titrator.

\section{Penetapan susut pengeringan.}

Sejumlah ekstrak ditimbang dan dimasukkan kedalam botol timbang dan dimasukan ke dalam ruang pengering suhu $105^{\circ} \mathrm{C}$ hingga bobot tetap.

\section{Penetapan kadar abu total.}

Sejumlah ekstrak ditimbang, dimasukkan ke dalam krus porselen yang telah dipijar dan ditara, dipijarkan perlahan-lahan hingga arang abis, dinginkan dan timbang hingga bobot tetap.. 


\section{Pengujian aktivitas penangkap radikal bebas dengan metode DPPH}

\section{Penetapan panjang gelombang serapan maksimum.}

Masing-masing sebanyak 1,0 mL ekstrak dan kontrol positif vitamin C $1 \mu \mathrm{g} / \mathrm{mL}$ ditambah $1 \mathrm{~mL}$ larutan DPPH 0,4 mM, dimasukkan ke dalam tabung reaksi yang telah ditara 5,0 mL diukur serapannya pada rentang panjang gelombang 400-600nm. Penentuan panjang gelombang serapan maksimum juga dilakukan untuk kontrol negatif.

\section{Penentuan operating time (waktu pengukuran).}

Masing-masing sebanyak 1,0 mL larutan ekstrak etanol kulit buah naga dan kontrol positif vitamn C $1 \mu \mathrm{g} / \mathrm{mL}$ ditambah $1 \mathrm{~mL}$ larutan DPPH 0,4 mM, selanjutnya diamati serapannya selama 0-60 menit pada panjang gelombang serapan maksimum.

\section{Uji aktivitas antioksidan dengan metode penangkap radikal bebas DPPH.}

\section{Pengukuran serapan.}

Masing-masing larutan uji dan larutan pembanding (kontrol positif) dengan beberapa konsentrasi diinkubasi pada suhu $37^{\circ} \mathrm{C}$ pada operating time, kemudian diukur pada panjang gelombang serapan maksimum menggunakan spektrofotometer cahaya tampak, sebagai larutan blangko digunakan etanol $70 \%$.

\section{Perhitungan \% penangkapan radikal bebas}

Data yang diperoleh dari pengukuran serapan digunakan untuk menghitung $\%$ penangkapan radikal bebas dengan rumus :

(\%) penangkap radikal

bebas $=\frac{\text { Serapan kontrol }- \text { serapan sampel }}{\text { Serapan kontrol }} \times 100 \%$

\section{Perhitungan nilai $\mathrm{IC}_{50}$}

Nilai $\mathrm{IC}_{50}$ ( Inhibition Concentration ) adalah konsentrasi senyawa uji (bpj) yang mampu menangkap radikal bebas sebesar $50 \%$.

Data yang diperoleh dianalisis secara statistik menggunakan persamaan regresi dari nilai konsentrasi (sumbu x) dan \% penangkap radikal bebas (sumbu y). Nilai $\mathrm{IC}_{50}$ yang semakin kecil menunjukkan semakin tingginya aktivitas penangkap radikal bebas.

Kurva hubungan antara konsentrasi dengan penangkap radikal bebas adalah sebagai berikut :

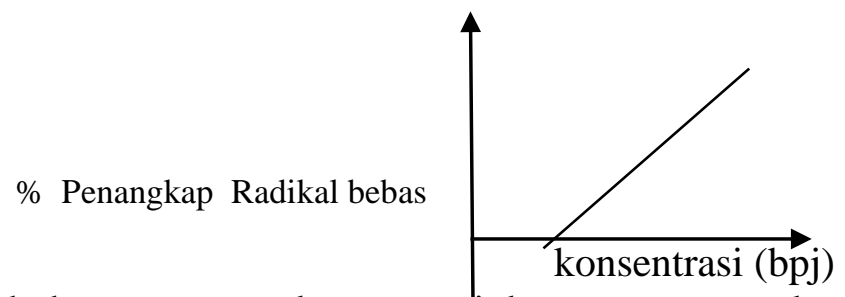

Gambar IV.1 kurva hubungan antara konsentrasi dengan \% penangkap radikal bebas

\section{Analisis Data.}

Data hasil penelitian berupa rata-rata nilai $\mathrm{IC}_{50}$ dari ekstrak kulit buah naga merahdan kulit buah naga putih dianalisis dengan uji anova satu arah dengan menggunakan progam SPSS. 


\section{Uji distribusi normal (Kolmogrov Smirnov test)}

Hipotesis $\quad: \mathrm{H}_{0}$ : Data distribusi normal

$\mathrm{H}_{1}$ : Data tidak terdistribusi normal

Nilai yang digunakan adalah $\alpha=0,05$

Kriteria pengujian : Jika $\mathrm{P}>\alpha$, maka $\mathrm{H}_{0}$ diterima

$$
\text { Jika } \mathrm{P}<\alpha \text {, maka } \mathrm{H}_{1} \text { diterima }
$$

\section{Uji homogenitas (Levene Test)}

Hipotesis : $\mathrm{H}_{0}$ : Varian antar perlakuan sama/homogen

$\mathrm{H}_{1}$ : Varian antar perlakuan berbeda/tidak homogen

Nilai $\alpha$ yang digunakan adalah $\alpha=0,05$

Kriteria pengujian : Jika $\mathrm{P}>\alpha$, maka $\mathrm{H} 0$ diterima

Jika $\mathrm{P}<\alpha$, maka $\mathrm{H} 1$ diterima

ANOVA. Uji ini dilakukan untuk mengetahui rata-rata lebih dari 2 sampel berbeda secara signifikan atau tidak.

Asumsi: $\quad \mathrm{H}_{0}=$ tidak ada perbedaan nyata rata-rata antar kelompok perlakuan

$\mathrm{H}_{1}=$ Ada perbedaan nyata rata- rata antar kelompok perlakuan

Nilai $\alpha$ yang digunakan pada $\alpha=0,05$

Kriteria pengujian : Jika $\mathrm{P}>\alpha$, maka $\mathrm{H}_{0}$ diterima ( tolak $\mathrm{H}_{1}$ ) Jika $\mathrm{P}<\alpha$, maka $\mathrm{H}_{1}$ diterima $\left(\mathrm{H}_{0}\right.$ ditolak

\section{HASIL DAN PEMBAHASAN}

Hasil determinasi tanaman menunjukkan bahwa buah naga yang digunakan dalam penelitian ini adalah buah naga merah ( Hylocereus polyrhizus (F.A.C. Weber)

Briton \& Rose dan buah naga putih ( Hylocereus undatus ( Haw.) Briton \& Rose) suku Cactaceae.

Hasil rendemen kulit buah naga merah dan kulit buah naga putih menunjukkan rendemen 15,35\% untuk kulit buah naga merah dan 17,56 \% untuk kulit buah naga putih. Kadar air masing-masing ekstrak kulit buah naga merah 8,51\% dan kulit buah naga putih $7,93 \%$. Kadar air masing-masing simplisia telah memenuhi syarat mutu untuk kadar air simplisia yaitu tidak lebih dari 10\%.(3).

Penetapan susut pengeringan ekstrak bertujuan untuk mengetahui kandungan air dan zat yang mudah menguap yang ada dalam sampel, selain itu tujuannya adalah untuk memberikan batasan maksimal (rentang) besarnya senyawa yang hilang pada proses pengeringan. Nilai atau rentang yang diperbolehkan terkait dengan kemurnian dan kontaminasi. Hasil penetapan susut pengeringan kulit buah naga merah yaitu 5,43\% dan kulit buah naga putih yaitu 3,67 \%, hasil susut pengeringan telah memenuhi syarat mutu untuk simplisia tidak lebih dari $10 \%$. (3)

Penetapan kadar abu ekstrak adalah memberikan gambaran kandungan mineral internal dan eksternal dalam simplisia, mulai dari proses awal sampai terbentuknya ekstrak. Kadar abu diperiksa untuk menetapkan tingkat pengotoran oleh logam-logam dan silikat. Hasil kadar abu ekstrak kulit buah naga merah sebesar 5,57 \% dan kulit buah naga putih $6,42 \%$.

Penetapan komponen senyawa aktif dalam kulit buah naga dilakukan secara kualitatif dengan menggunakan beberapa pereaksi spesifik yang hasilnya dapat dilihat pada tabel 1. Hasil penapisan fitokimia yang dilakukan pada ektstrak etanol kulit buah naga merah dan kulit buah naga putih, menunjukkan bahwa tidak ada perbedaan kandungan golongan metabolit sekunder, kedua ekstrak tersebut positif memiliki kandungan metabolit sekunder golongan flavonoid, saponin, steroid, triterpenoid,dan kumarin.(5) 
Tabel .1. Hasil penelitian penapisan fitokimia ekstrak kulit naga merah dan naga putih

\begin{tabular}{|l|c|c|}
\hline \multirow{2}{*}{ Golongan senyawa } & \multicolumn{2}{|c|}{ Hasil pengamatan } \\
\cline { 2 - 3 } & $\begin{array}{c}\text { Ekstrak etanol kulit } \\
\text { buah naga merah }\end{array}$ & $\begin{array}{c}\text { Ekstrak etanol kulit } \\
\text { buah naga putih }\end{array}$ \\
\hline Alkaloid & - & - \\
\hline Flavonoid & + & + \\
\hline Saponin & + & + \\
\hline Tanin & - & - \\
\hline Kuinon & - & - \\
\hline Steroid \& triterpenoid & + & + \\
\hline Kumarin & + & + \\
\hline Minyak atsiri & - & - \\
\hline
\end{tabular}

Keterangan $+=$ memberikan reaksi positif

- $\quad=$ memberikan reaksi negatif

Pengujian aktivitas penangkap radikal bebas dari ekstrak kulit buah naga merah dan kulit buah naga putih, dilakukan dengan menggunakan pereaksi DPPH metode spektrofotometri UV-Vis dengan vitamin C sebagai kontrol positif. DPPH sebagai radikal bebas kemudian ditangkap radikal bebasnya oleh antioksidan yang terdapat dalam bahan uji membentuk 1,1-difenil-2-pikrilhidrazin. Adanya aktivitas antioksidan dari bahan uji mengakibatkan terjadinya perubahan warna larutan DPPH. Metode DPPH merupakan salah satu metode pengukuran antioksidan yang sederhana, murah, cepat serta hanya memerlukan sedikit sampel. Metode ini paling umum digunakan untuk mengevaluasi aktivitas antoksidan, khususnya senyawa fenol atau polifenol. (6).

Aktivitas penangkap radikal bebas didasarkan pada kemampuan larutan ekstrak kulit buah naga dalam menangkap radikal bebas DPPH (1,1-difenil-2-pikrilhidrazil). DPPH sebagai radikal bebas bereaksi dengan antioksidan ekstrak kulit buah naga, akibatnya 1,1-difenil-2-pikrilhidrazil yang semula berwarna ungu karena merupakan suatu radikal bebas akan mengikat atom hidrogen yang dilepaskan oleh zat uji membentuk senyawa 1,1-difenil-2-pikrihidrazin yang berwarna kuning stabil. Senyawa fenol yang kehilangan atom hidrogen akan menjadi radikal bebas baru yang stabil namuntidak reaktif karena adanya resonansi inti aromatik. Intensitas perubahan warna dapat diukur menggunakan spektrofotometer cahaya tampak pada panjang gelombang $517 \mathrm{~nm}$ (4).

Tahap pengujian senyawa dengan metode spektrofotometri cahaya tampak adalah penetapan panjang gelombang serapan maksimum. Hasil penetapan panjang gelombang serapan maksimum larutan blanko DPPH 0,4 mM menggunakan spektrofotometri UV-Vis adalah $518 \mathrm{~nm}$ dengan serapan maksimum 0,8194. Menurut pustaka, terdapat beberapa panjang gelombang serapan maksimum larutan DPPH yaitu $515 \mathrm{~nm}, 516 \mathrm{~nm}, 517 \mathrm{~nm}, 518$ $\mathrm{nm}$ dan $520 \mathrm{~nm}$.

Pada penentuan operating time (waktu pengukuran), menunjukkan bahwa DPPH telah bereaksi secara optimal dengan senyawa uji. Hasil penelitian menunjukkan serapan ekstrak etanol kulit buah naga pada panjang gelombang serapan maksimum stabil pada menit ke-25 sampai menit ke-37.

Ekstrak kulit buah naga merah dan kulit buah naga putih yang diperoleh dari hasil maserasi dengan etanol 70\%. Aktivitas antioksidannya diuji menggunakan metode peredaman radikal bebas dengan pereaksi DPPH dan Vitamin C sebagai kontrol positif . Hasil uji aktivitas antioksidan vitamin $\mathrm{C}$ sebagai kontrol positif dapat dilihat pada Tabel 2 dan Gambar 1, sedangkan hasil uji aktivitas antioksidan pada kulit buah naga putih pada 
Tabel 3 dan Gambar 2, dan untuk kulit buah naga merah dapat dilihat pada Tabel 4 dan Gambar 3.

Dari hasil aktivitas antioksidan terhadap vitamin $\mathrm{C}$ sebagai kontrol positif didapat nilai $\mathrm{IC}_{50} 3,5 \mu \mathrm{g} / \mathrm{mL}$, yang menunjukan aktivitas antioksidan vitamin $\mathrm{C}$ yang sangat kuat karena nilai $\mathrm{IC}_{50}$ yang didapat kurang dari $50 \mu \mathrm{g} / \mathrm{mL}$.

Dari hasil aktivitas antioksidan yang dilakukan pada kulit buah naga putih diperoleh nilai $\mathrm{IC}_{50}$ yaitu $101,7 \mu \mathrm{g} / \mathrm{mL}$. Nilai $\mathrm{IC}_{50}$ ini masuk dalam rentang kategori antioksidan sedang dan bila dibandingkan dengan hasil aktivitas antioksidan pada vitamin $\mathrm{C}(3,8 \mu \mathrm{g} / \mathrm{mL})$.

Tabel 2. Hasil Uji Aktivitas Antioksidan Vitamin C Sebagai Kontrol Positif

\begin{tabular}{|c|c|c|c|c|c|c|c|}
\hline \multirow{2}{*}{$\begin{array}{l}\text { Konsentrasi } \\
\text { (bpj) }\end{array}$} & \multirow[t]{2}{*}{$\mathrm{Ab}$} & \multicolumn{3}{|c|}{ As } & \multirow{2}{*}{$\begin{array}{l}\text { As } \\
\text { Rata- } \\
\text { rata }\end{array}$} & \multirow{2}{*}{$\begin{array}{l}\text { Penagkap } \\
\text { radikal } \\
\text { bebas }(\%)\end{array}$} & \multirow{2}{*}{$\begin{array}{l}\text { Nilai } \\
\mathrm{IC}_{50}( \\
\mu \mathrm{g} / \mathrm{mL})\end{array}$} \\
\hline & & $\mathrm{As}_{1}$ & $\mathrm{As}_{2}$ & $\mathrm{As}_{3}$ & & & \\
\hline 1,0289 & \multirow{7}{*}{0,8393} & 0,6769 & 0,6536 & 0,6575 & 0,6627 & 21,0413 & \multirow{7}{*}{3,8099} \\
\hline 2,0578 & & 0,5671 & 0,5861 & 0,5508 & 0,568 & 32,3246 & \\
\hline 3,0867 & & 0,4604 & 0,4854 & 0,4793 & 0,4750 & 43,4052 & \\
\hline 4,1156 & & 0,3539 & 0,3534 & 0,3742 & 0,3605 & 57,0475 & \\
\hline 5,1445 & & 0,2924 & 0,2882 & 0,2989 & 0,2932 & 65,0739 & \\
\hline 6,1734 & & 0,2099 & 0,2128 & 0,2336 & 0,2188 & 73,9307 & \\
\hline 7,2023 & & 0,1804 & 0,1966 & 0,1879 & 0,1883 & 77,5646 & \\
\hline
\end{tabular}

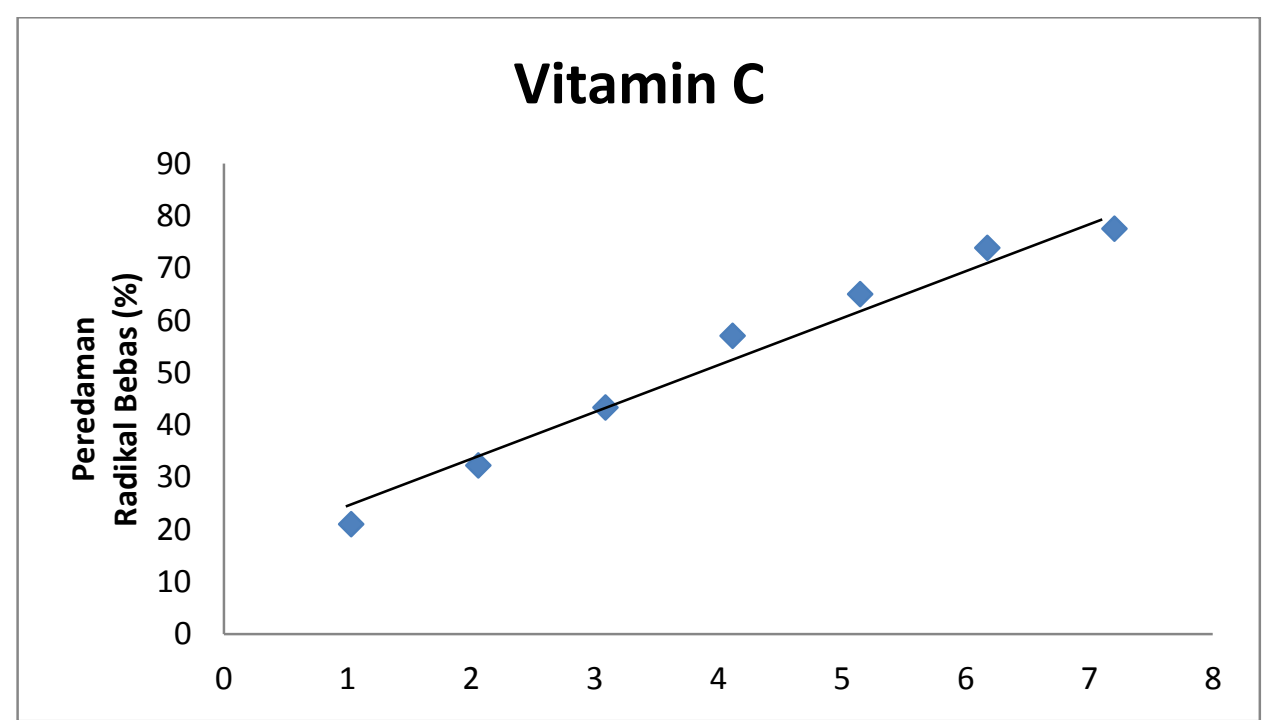

Gambar 1. Kurva hubungan antara konsentrasi (bpj) dengan penangkap radikal bebas (\%) pada vitamin $\mathrm{C}$ 
Tabel 3. Hasil uji aktivitas antioksidan ekstrak kulit buah naga putih

\begin{tabular}{|c|c|c|c|c|c|}
\hline $\begin{array}{l}\text { Ekstrak } \\
\text { kulit naga } \\
\text { putih } \\
\end{array}$ & $\begin{array}{l}\text { Konsentrasi } \\
(\mu \mathrm{g} / \mathrm{mL})\end{array}$ & $\begin{array}{l}\text { Serapan } \\
\text { blangko }\end{array}$ & $\begin{array}{l}\text { Serapan } \\
\text { sampel }\end{array}$ & $\begin{array}{c}\text { Peredaman } \\
\text { radikal bebas } \\
(\%)\end{array}$ & 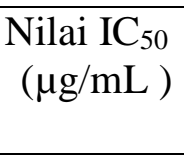 \\
\hline \multirow{7}{*}{ I } & 19,8872 & \multirow{7}{*}{0,8295} & 0,6502 & 21,6688 & \multirow{7}{*}{104,0149} \\
\hline & 39,7744 & & 0,5828 & 29,7408 & \\
\hline & 59,6616 & & 0,5624 & 32,2001 & \\
\hline & 79,5488 & & 0,4718 & 43,1224 & \\
\hline & 99,436 & & 0,4248 & 48,7884 & \\
\hline & 119,3232 & & 0,3587 & 56,7571 & \\
\hline & 139,2104 & & 0,3291 & 60,3255 & \\
\hline \multirow{7}{*}{ II } & 20,0713 & \multirow{7}{*}{0,8257} & 0,6532 & 20,8914 & \multirow{7}{*}{101,4211} \\
\hline & 40,1425 & & 0,5785 & 29,9382 & \\
\hline & 60,2138 & & 0,5539 & 32,9175 & \\
\hline & 80,2850 & & 0,4628 & 43,9506 & \\
\hline & 100,3563 & & 0,4154 & 49,6912 & \\
\hline & 120,4276 & & 0,3461 & 58,0840 & \\
\hline & 140,4988 & & 0,3100 & 62,4561 & \\
\hline \multirow{7}{*}{ III } & 20,0713 & \multirow{7}{*}{0,8388} & 0,6568 & 21,6977 & \multirow{7}{*}{99,7992} \\
\hline & 40,1425 & & 0,5809 & 30,7463 & \\
\hline & 60,2138 & & 0,5543 & 33,9175 & \\
\hline & 80,2850 & & 0,4666 & 44,3729 & \\
\hline & 100,3563 & & 0,4212 & 49,7854 & \\
\hline & 120,4276 & & 0,3401 & 59,4539 & \\
\hline & 140,4988 & & 0,3147 & 62,4821 & \\
\hline \multicolumn{5}{|c|}{ Rata-rata $\mathrm{IC}_{50}(\mathrm{bpj})$} & $\begin{array}{l}101,7451 \pm \\
2,13\end{array}$ \\
\hline
\end{tabular}

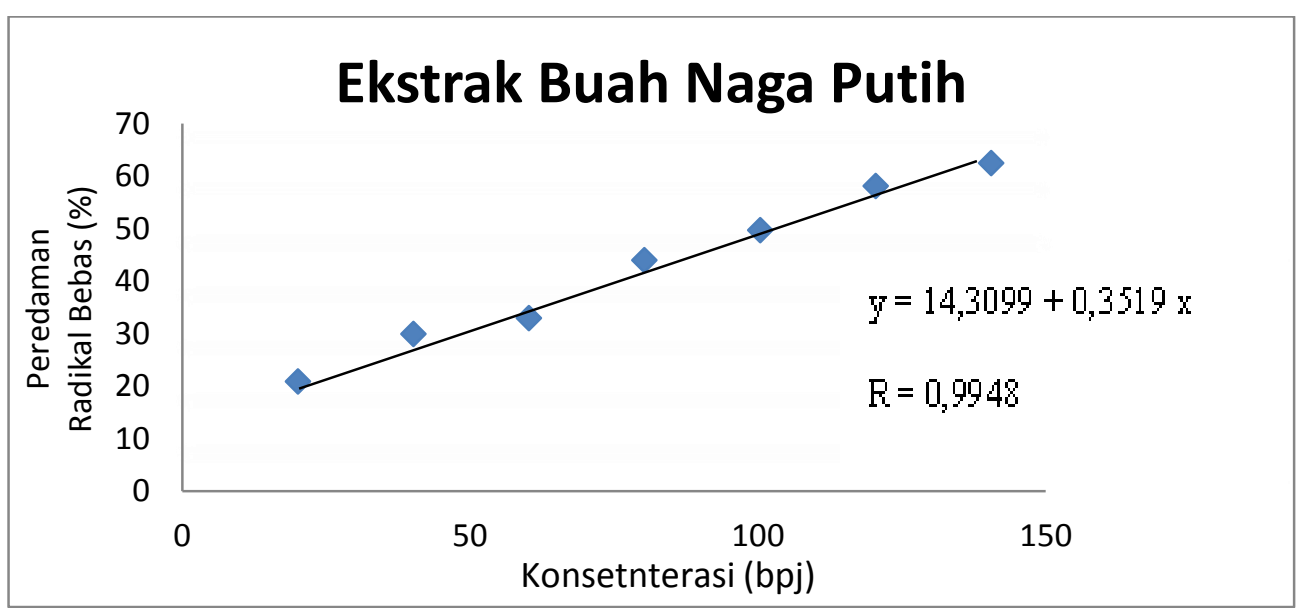

Gambar 2. Kurva hubungan antara konsentrasi (bpj) dengan penangkap radikal bebas (\%) pada Ekstrak kulit buah naga putih 
Tabel 4. Hasil uji aktivitas antioksidan ekstrak kulit buah naga merah

\begin{tabular}{|c|c|c|c|c|c|}
\hline $\begin{array}{l}\text { Ekstrak } \\
\text { kulit naga } \\
\text { merah }\end{array}$ & $\begin{array}{l}\text { Konsentrasi } \\
\text { (bpj) }\end{array}$ & $\begin{array}{l}\text { Serapan } \\
\text { blangko }\end{array}$ & $\begin{array}{l}\text { Serapan } \\
\text { sampel }\end{array}$ & $\begin{array}{c}\text { Penagkap } \\
\text { radikal bebas } \\
(\%)\end{array}$ & $\begin{array}{l}\text { Nilai IC } 50 \\
\quad(\mu \mathrm{g} / \mathrm{mL})\end{array}$ \\
\hline \multirow{7}{*}{ I } & 18,6646 & \multirow{7}{*}{0,8113} & 0,6720 & 17,1699 & \multirow{7}{*}{78,9781} \\
\hline & 37,3292 & & 0,5984 & 26,2418 & \\
\hline & 55,9938 & & 0,4862 & 40,0715 & \\
\hline & 74,6548 & & 0,3800 & 53,1616 & \\
\hline & 93,323 & & 0,3612 & 55,4789 & \\
\hline & 111,9876 & & 0,2538 & 68,1622 & \\
\hline & 130,6522 & & 0,2101 & 74,103 & \\
\hline \multirow{7}{*}{ II } & 18,8476 & \multirow{7}{*}{0,8585} & 0,6848 & 20,2329 & \multirow{7}{*}{74,4548} \\
\hline & 37,6952 & & 0,5889 & 31,4036 & \\
\hline & 56,5428 & & 0,4746 & 44,7175 & \\
\hline & 75,3905 & & 0,3880 & 54,8048 & \\
\hline & 94,2381 & & 0,3406 & 60,3262 & \\
\hline & 113,0857 & & 0,2838 & 66,9423 & \\
\hline & 131,9333 & & 0,2173 & 74,6884 & \\
\hline \multirow{7}{*}{ III } & 19,0306 & \multirow{7}{*}{0,8587} & 0,6717 & 21,7771 & \multirow{7}{*}{75,1418} \\
\hline & 38,0621 & & 0,5966 & 30,5229 & \\
\hline & 57,0918 & & 0,4664 & 45,6853 & \\
\hline & 76,1224 & & 0,3762 & 56,1896 & \\
\hline & 95,153 & & 0,3698 & 56,9349 & \\
\hline & 114,1836 & & 0,2734 & 68,1612 & \\
\hline & 133,2142 & & 0,2247 & 73,8325 & \\
\hline \multicolumn{5}{|c|}{ Rata-rata $\mathrm{IC}_{50}(\mathrm{bpj})$} & $\begin{array}{l}76,1916 \pm \\
2,44\end{array}$ \\
\hline
\end{tabular}

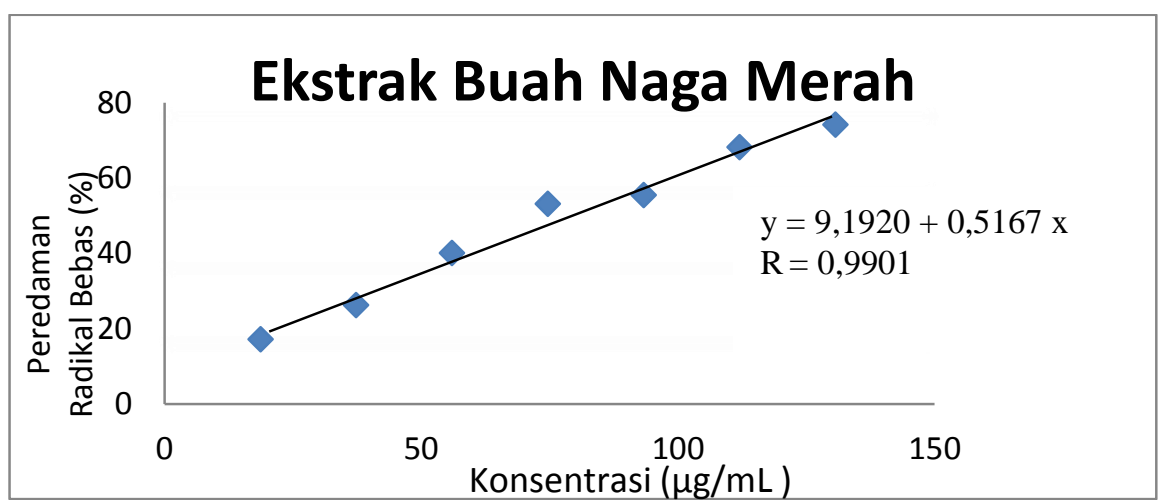

Gambar 3. Kurva hubungan antara konsentrasi (bpj) denganPeredaman radikal bebas (\%) pada Ekstrak kulit buah naga merah

Dari hasil aktivitas antioksidan pada kulit buah naga merah diperoleh nilai $\mathrm{IC}_{50}$ yaitu $76,1 \mu \mathrm{g} / \mathrm{mL}$. Nilai $\mathrm{IC}_{50}$ ini masuk dalam rentang kategori antioksidan kuat, sedangkan aktivitas antioksidan pada vitamin $\mathrm{C}(3,8 \mu \mathrm{g} / \mathrm{mL})$ sangat kuat.. Rangkuman hasil uji aktivitas antioksidan dengan metode radikal bebas DPPH pada vitamin $\mathrm{C}$ sebagai kontrol positif dan ekstrak kulit buah naga dapat dilihat pada tabel 5. 
Tabel 5. Rangkuman hasil uji antioksidan dengan DPPH

\begin{tabular}{|c|c|c|}
\hline \multicolumn{3}{|c|}{ Nilai IC 50} \\
\hline Vitamin C & $\begin{array}{c}\text { Ekstrak etanol kulit } \\
\text { buah naga merah } \\
(\mu \mathrm{g} / \mathrm{mL})\end{array}$ & $\begin{array}{c}\text { Ekstrak etanol kulit } \\
\text { buah naga putih } \\
(\mu \mathrm{g} / \mathrm{mL})\end{array}$ \\
\hline 3,80 & 76,1 & 101,7 \\
\hline
\end{tabular}

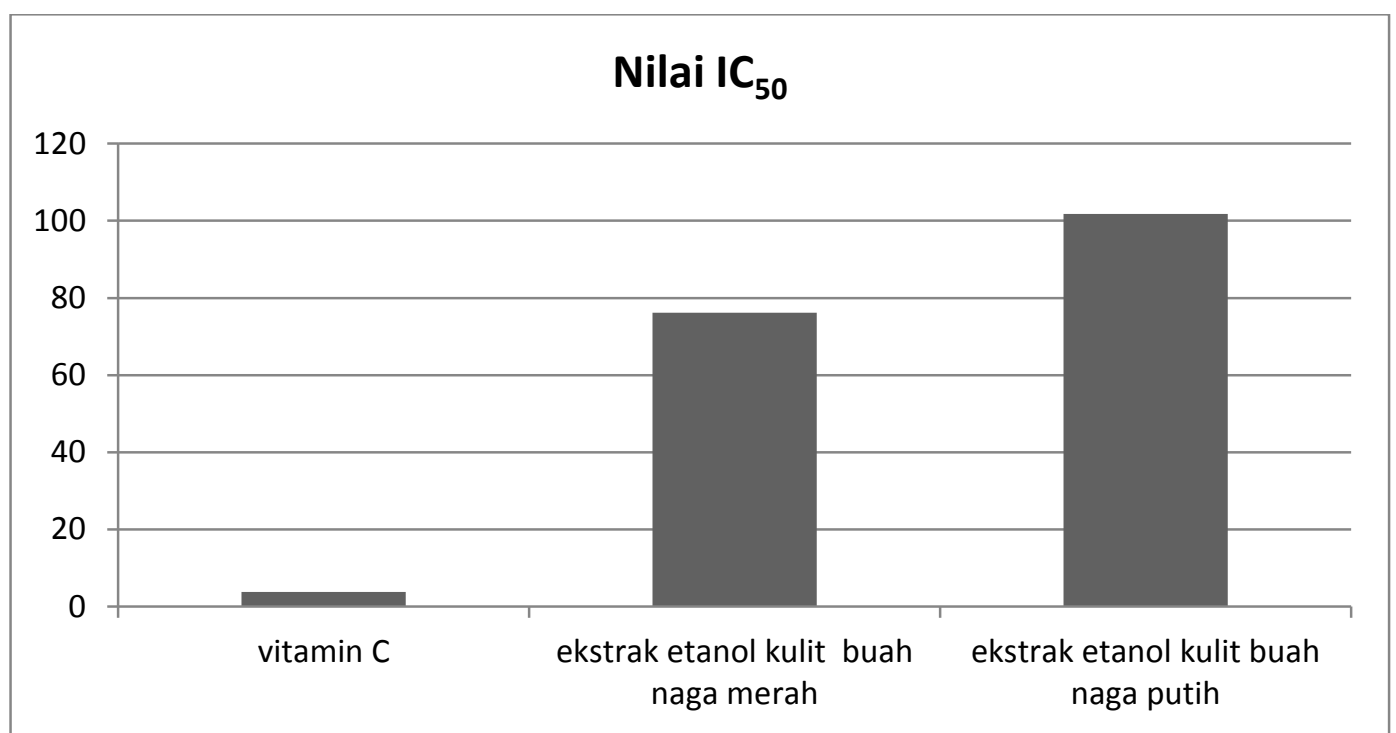

Gambar 4. Grafik perbandingan nilai $\mathrm{IC}_{50}$ Vit. C, kulit buah naga merah dan kulit buah naga putih

Dari tabel 5 menunjukkan bahwa nilai $\mathrm{IC}_{50}$ ekstrak etanol kulit buah naga merah dan kulit buah naga putih lebih besar dibandingkan dengan nilai $\mathrm{IC}_{50}$ dari baku pembanding Vitamin $\mathrm{C}$, dimana semakin kecil nilai $\mathrm{IC}_{50}$ maka semakin tinggi aktivitas antioksidannya.

Suatu senyawa dikatakan memiliki aktivitas antioksidan jika memiliki nilai $\mathrm{IC}_{50}$ kurang dari $200 \mu \mathrm{g} / \mathrm{mL}$. Kulit buah naga merah memiliki nilai $\mathrm{IC}_{50}$ sebesar 76,19 $\mu \mathrm{g} / \mathrm{mL}$ termasuk dalam golongan yang memiliki aktivitas antioksidan kuat ( range $50-100$ $\mu \mathrm{g} / \mathrm{mL}$ ). Sedangkan, kulit buah naga putih memiliki nilai $\mathrm{IC}_{50}$ sebesar $101,75 \mu \mathrm{g} / \mathrm{mL}$ termasuk dalam golongan yang memiliki aktivitas antioksidan sedang ( range 100-150 $\mu \mathrm{g} / \mathrm{mL}$ ). Hasil diatas menunjukkan bahwa ekstrak etanol kulit buah naga merah mempunyai aktivitas lebih tinggi. Berdasarkan hasil pengujian Anova, ada perbedaan nilai $\mathrm{IC}_{50}$ dari kulit buah naga merah dengan nilai $\mathrm{IC}_{50}$ kulit buah naga putih.

\section{KESIMPULAN}

Aktivitas penangkapan radikal bebas ekstrak kulit buah naga merah lebih kuat dibandingkan dengan ekstrak kulit buah naga putih dan lebih lemah dibandingkan dengan vitamin C. Hal ini ditunjukkan dengan nilai $\mathrm{IC}_{50}$ ekstrak kulit buah naga merah 76,19 \pm $2,44 \mu \mathrm{g} / \mathrm{mL}$ dan ekstrak etanol kulit buah naga putih dengan nilai $\mathrm{IC}_{50}$ sebesar 101,74 \pm $2,13 \mu \mathrm{g} / \mathrm{mL}$, sedangkan vitamin $\mathrm{C}$ nilai $\mathrm{IC}_{50}$ sebesar $3,80 \mu \mathrm{g} / \mathrm{mL}$.

\section{UCAPAN TERIMAKASIH}

Terimakasih penulis sampaikan kepada Gigin Devita Sari. S.Si. yang telah banyak membantu dalam penyelesaian penelitian ini. 


\section{DAFTAR PUSTAKA}

1. Soedarya A. Agribisnis buah naga. Bandung: Penerbit Pustaka Grafika; 2007. h.1-2.

2. Amrun H , Umayah U. Uji Aktivitas Antioksidan Ekstrak buah naga (Hylocereus undatus (Haw) Britt. \& Rose).Jurnal ilmu dasar. 2007; 8(1):83-90.

3. Windholz M, editor. The Merck Index an Encyclopedia of chemicals, drugs, and biologicals. 10th ed. USA: Merck and Co.,Inc; 2006. p. 3332.

4. Departemen Kesehatan Republik Indonesia. Parameter standar umum ekstrak tumbuhan obat. Jakarta : Direktorat Jendral Pengawasan obat dan makanan Direktorat Pengawasan Obat tradisional; 2000.h.17-46.

5. Djamil R, Anelia T. Penapisan Fitokimia, Uji BSLT, dan Uji Antioksidan Ekstrak Metanol beberapa Spesies Papilionaceae. Jurnal Ilmu Kefarmasian Indonesia 2009; 7(2).h. 69.

6. Molyneux P. The use of the stable free radical 1,1-diphenyl-2-picrylhirazyl (DPPH) for estimating antioxidant activity. Songklanakarin J. Sci. Technol. 2004;26(2):211-219. 